\title{
INHIBITION OF STRESS-CORROSION CRACKING WITH PHOSPHATE SOLUTIONS
}

\author{
A. P. Larrick
}

APRIL 1968

\section{AEC RESEARCH \& DEVELOPMENT REPORT}

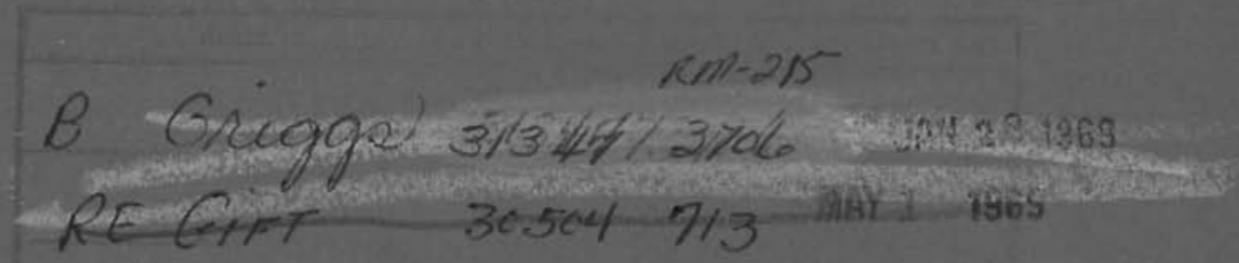




\title{
LEGAL NOTICE
}

This report was prepared as an account of Governmant sponsored work. Neither the United States. nor the Commision, nor any person acting on behalf of the Commission:

A. Makes any warranty or representotion, expressed of implied, with respect to the accuracy, com: plateness, or usefulness of the information contained in this report, or that the use of any information, apparalus, method, of process disclosed in this report may not infringe privately owned cights: or

B. Assumes any liabilifies with respect to the use of. or for damages resulting from the use of ony iniormation, apparatus; method, of process disclosed in this report.

As used in the above, "person octing on behalf of the Cammission" includes any employse or contractor of the Commission, or employee of such contractor, to the extent that iuch emplayee or conIractar of the Commission, or employee of such contractor prepares, disseminates, or provides access to, any information pursuant to his employmeat or controct with the Commissions of his emiployment with such contractor.

\author{
PACIFIC NORTHWEST LABORATORY \\ RICHLAND, WASHINGTON \\ operated by \\ BATTELLE MEMORIAL INSTITUTE
}

for the

UNITED STATES ATOMIC ENERGY COMMISSION UNDER CONTRACT AT(45-1)-1830 
$B N W L=753$

UC -80

Reactor Technology

INHIBITION OF STRESS $\approx$ CORROSION

CRACK ING WITI PHOSPHATE SOLUTIONS

By

Alvin $P$ 。 Larrick

Surface and Coolant Chemistry Section Chemistry and Chemical Fngineering Department

April。 1968

IIRST UNRESTRICTED
DISTRIRUTION MADE

PACIFIC NORTHWEST LABORATORY

RICHLAND, WASHINGTON 
BNWL -753

INHIBITION OF STRESS-CORROSION
CRACKING WITH PHOSPHATE SOLUTIONS

Alvin $P$ 。 Larrick

\section{INTRODUCTION}

During preoperation hydrostatic testing of the $N$ Reactor primary loop system in 1963, two of the steam generators were found to be leaking. In one unit, $3 \mathrm{~B}$, tubes were leaking at the tube sheet area due to stress corrosion cracking and in the other unit, $4 \mathrm{~A}$, leaking occurred due to a severe intergranular attack found in small localized spots on the 304 SS tubing. The latter unit had attack in 50 percent of the tubing of a severity which necessitated its retubing. Inconel 600 was selected for the retubing material. This type of attack was also found in several other steam generators.

With subsequent startup and over two years of operation of the reactor, numerous failures have occurred. These failures are thought to be due to stress-assisted intergranular corrosion and fatigue. The tube failure problem became so serious that it was planned to retube several or all of the 304 SS tubed steam generators.(1) Both steam generators in Cel1 3 have now been retubed with Inconel 600 and work has been initiated on retubing others.

The retubing of a steam generator can be quite costly, both from the expense of new materials and the expense of labor involved. With this high economic incentive, methods to stop the corrosion failures and remove the necessity of retubing were investigated. A literature search indicated that sodium phosphate additions to the water on the secondary side of the steam generators showed the most potential in reducing or eliminating the tubing failures. It is well documented in the literature that phosphates are able to stop stress-corrosion cracking on new, uncracked 304 stainless steel, but only two instances of phosphate additions having stopped additional stress-corrosion cracking on material with existing cracks have been reported. $(2,3)$ Even in these latter two instances there was not positive proof that the phosphate additions were responsible for mitigation of the stress corrosion cracking. 
Because of the meager evidence available on inhibition of stress-corrosion cracking with phosphates it was decided to test the inhibition of stress corrosion cracking on steam generator tubing by phosphates in laboratory tests, rather than expend the large amount of money for equipment modifications to add phosphate directly to the steam generators. This document presents the results of the laboratory tests.

\section{SUMMARY AND CONCLUSIONS}

Autoclave tests were conducted for an eight-month period to compare the corrosiveness and stress-corrosion cracking inhibition qualities of alternate N Reactor steam generator secondary system water chemistries to those of the zero solids (hydrazine-morpholine) water treatment presently used. Seven tests with phosphate levels from 0 to $1000 \mathrm{ppm}$, sulfite levels from 0 to $100 \mathrm{ppm}$, hydrazine levels from 0 to $15 \mathrm{ppm}$ and morpholine levels of $2 \mathrm{ppm}$ were conducted. After four months exposure, stress corrosion cracking of 304 SS tubing obtained from an $N$ Reactor steam generator had occurred in both the liquid and vapor phases of solutions not containing phosphates, and in the vapor phase over solutions containing phosphate, but not on samples immersed in the liquid phase of any solution containing phosphate ion.

At six months exposure one small $10 \mathrm{mil}$ long crack was noted on a sample in the liquid phase of the solution containing $1000 \mathrm{ppm}$ phosphate, 15 ppm hydrazine; at eight months exposure similar cracks were noted on a sample from this solution and from a sample containing 1000 ppm phosphate, $100 \mathrm{ppm}$ sulfite. Cracks were not found on samples in the liquid phase of three other solutions containing 50-100 ppm phosphate. Large cracks were found on samples in the liquid phase of solutions without phosphate and on samples in the vapor phases of most solutions. The phosphate solutions provided cracking inhibition under extremely adverse conditions since the solutions were contaminated with chlorides and oxygen, elements which provide an environment very conducive to stress-corrosion cracking.

Stress-corrosion cracking did not occur on other lots of unsensitized 304 SS and 304 SS heat treated similarly to the steam generator tubing 
nor did it occur on Inconel 600, Incoloy 800 or A212 CS. Weight losses on the stainless steel, Inconel and Incoloy samples were negligible. Total penetration on the carbon steel after 8 months ranged from 0.02 to $0.3 \mathrm{mils}$ in the various solutions.

\section{EXPERIMENTAL}

Corrosion Samples

Corrosion samples of Type 304 stainless steel, Inconel 600, Incoloy 800 and ASTM A212 carbon steel were employed in this test.

The 304 SS was obtained from two sources: Tubing removed from N Reactor Steam Generator 4AS (row 37, line 1), and sheet material manufactured by McLouth Steel Corp., Detroit, Mich. The 5/8-inch OD x 0.049 wall steam generator tubing was cut into 1/2-inch long cylinders, a small longitudinal segment of metal was cut away and the sample was stressed as shown in Figure 1. The sheet 304 SS was cut into strips and rolled around a mandrel to make coupons similar in size to the tubing samples and stressed as shown in Figure 1a. The sheet thickness was 0.031 inch. Analysis of the sheet material is given in Table 1; the exact analysis of the tubing material is not known but it was within the ASTM nominal composition limits. One-half the sheet material samples were heat treated to place them in a sensitized condition similar to the steam generator tubing. The heat treatment employed simulated the higher temperature range heat treatment to which Steam Generator $3 B$ was subjected during fabrication (Figure 2).

Inconel 600 samples were cut from Steam Generator $4 \mathrm{~A}$, tubes 4ASR55L35 and 4ASR55L37. These tubes were removed from service after approximately one year of operation. The samples were stressed before corrosion testing as shown in Figure la. The nominal composition of Inconel 600 is given in Table 1 .

Incoloy 800 and A212 carbon steel samples were manufactured from sheet material and stressed similar to the 304 SS sheet material samples. Sheet stock thicknesses were 0.063 inch and 0.070 inch on the carbon steel and Incoloy 800, respectively。 Nominal compositions are given in Table 1 。 


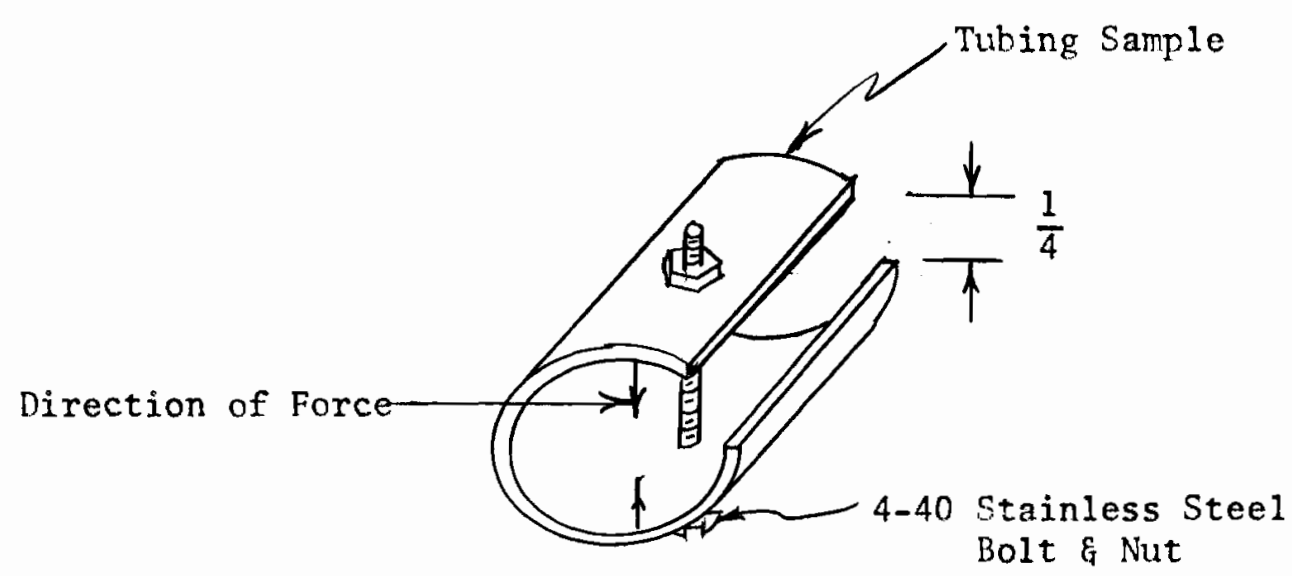

a) Method of obtaining tensile stress on OD of cylinder.

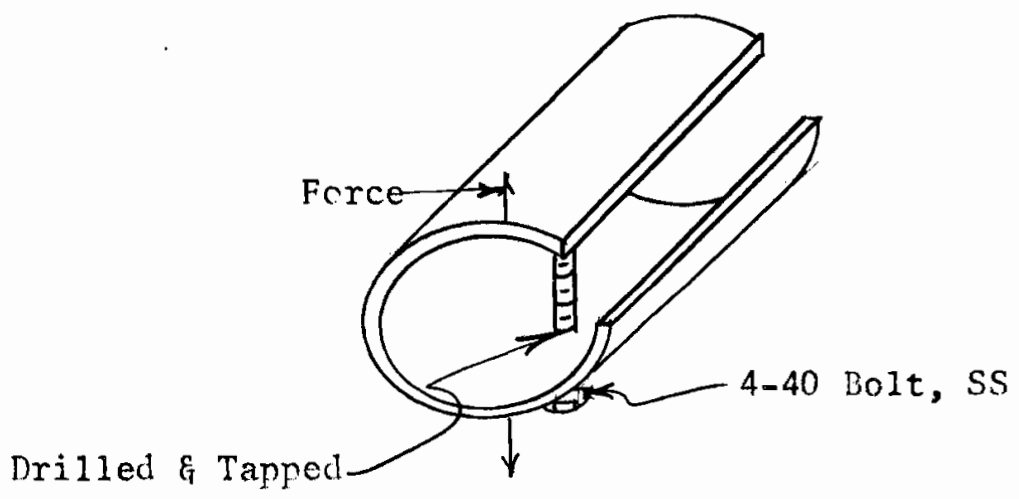

b) Method of obtaining tensile stress on Io of cylinder.

FIGURE 1

METHOD OF STRESSING CORROSION SAMPLES 


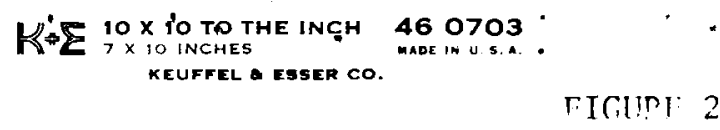

IFAT TRFATTIFNT CIRVF FOR SENSITIZFN 304 SS COUPOAS

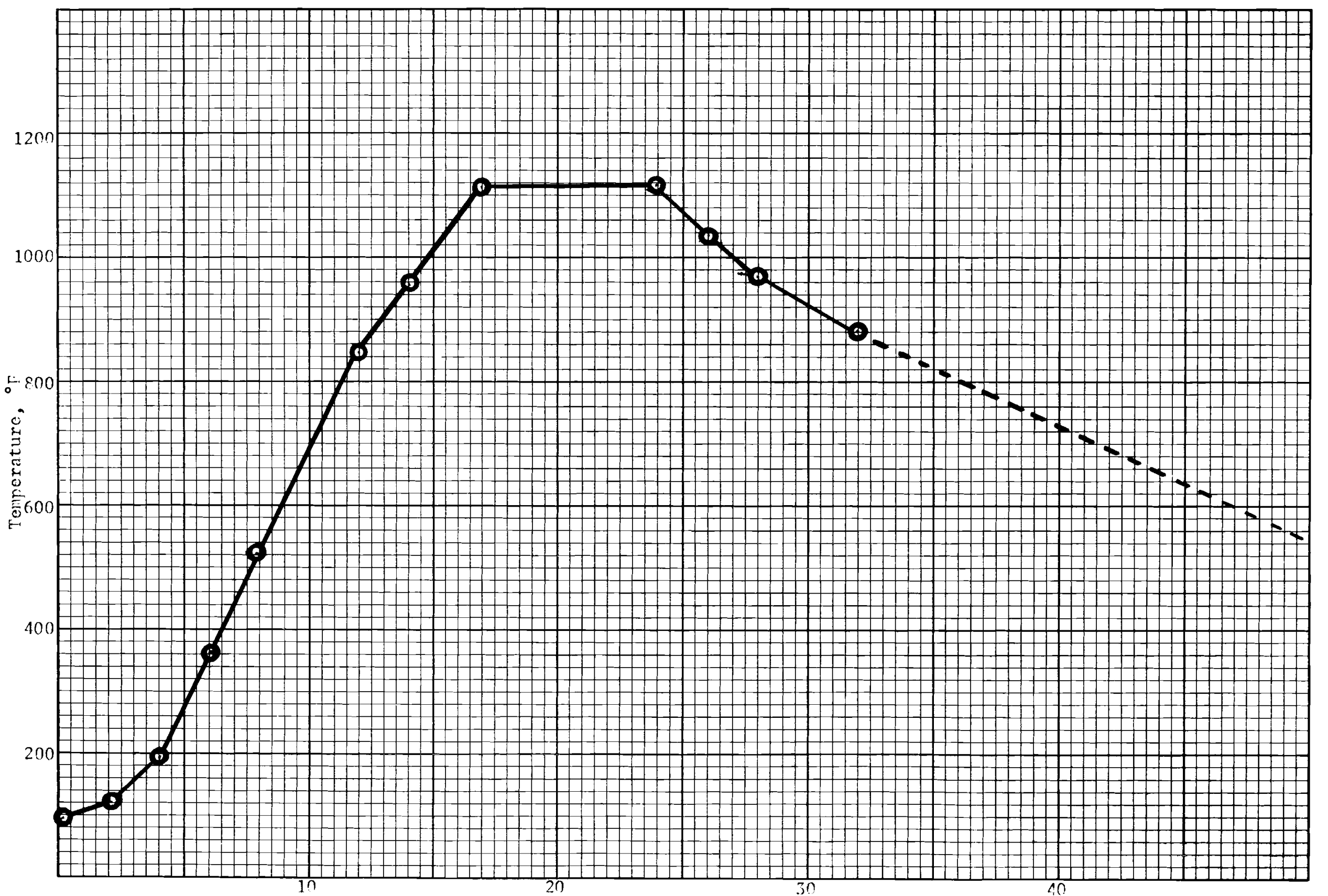

rlansed Time, !ours 
TABLE 1

COMPOSITION OF COUPON MATERIALS

\begin{tabular}{|c|c|c|c|c|c|c|c|c|c|c|c|c|}
\hline Alloy & $\mathrm{C}$ & Mn & $\mathrm{P}$ & $S$ & $\mathrm{Si}$ & $\mathrm{Cr}$ & $\mathrm{Ni}$ & Mo & $\mathrm{Cu}$ & Co & $\mathrm{Fe}$ & Other \\
\hline 304 SS Tubing* & $\begin{array}{l}0.08 \\
\max \end{array}$ & & & & & 19 & 9 & & & 0.03 & bal & \\
\hline 304 SS Strip Samples & 0.062 & 1.66 & 0.018 & 0.008 & 0.55 & 18.07 & 8.62 & 0.24 & 0.18 & 0.11 & bal & \\
\hline Incoloy 800 & 0.06 & 0.89 & - & 0.007 & 0.41 & 20.75 & 32.03 & & 0.13 & & 45.70 & $0.75 \mathrm{Al}$ \\
\hline Inconel 600 * & 0.15 & $\begin{array}{l}1.0 \\
\max \end{array}$ & - & $\begin{array}{l}0.015 \\
\max \end{array}$ & $\begin{array}{l}0.5 \\
\max \end{array}$ & $\begin{array}{l}14- \\
17.0\end{array}$ & ba1 & - & $\begin{array}{l}0.5 \\
\max \end{array}$ & - & $\begin{array}{l}6.0- \\
10.0\end{array}$ & \\
\hline A212 Carbon Steel* & 0.31 & 0.90 & 0.04 & 0.05 & $\begin{array}{l}0.15- \\
0.30\end{array}$ & & & & & & bal & \\
\hline
\end{tabular}

ॠNominal. 
Test Apparatus Description and Operation

The corrosion samples were charged into test sections fabricated from $21 / 2$ inch carbon steel pipe as shown in Figure 3. Makeup water was pumped from the makeup tanks into the bottom of the test chambers at a rate of approximately 1.5 to 2 liters/day and allowed to spill to drain through the overflow spout located two-thirds up the height of the test section. Samples were placed on stainless steel hooks in the liquid, interface, and vapor regions of the test section.

Seven test sections, each with a separate source of makeup water, were installed in an autoclave which operated with 100 psi steam. Prior to charging the test samples, the autoclave was operated for one week with $100 \mathrm{psi}$ steam to prefilm the test sections. The overflow from the test chambers exited from the autoclave with the steam condensate. An eighth set of samples was installed in another autoclave completely filled with water at the same temperature $\left(164{ }^{\circ} \mathrm{C}\right)$ as in the 100 psi steam autoclave to act as a statistical control. Water from the same makeup tank used for one of the test chambers (No.2) in the steam-heated autoclave was pumped into the control autoclave at a rate of 19 liters/day.

Sample discharges were made at two weeks and 1, 2, 4, 6 and 8 months exposure. The autoclave was slowly cooled before discharge while makeup water addition continued in order to prevent flashing. the water in the test sections into steam.

One deviation in the above operating conditions occurred in the control autoclave after one month of operation. The temperature controller failed and allowed the temperature to increase to $450{ }^{\circ} \mathrm{C}$ (superheated steam) for a seven-hour period. Examination of the coupons indicated nothing unusual and the test was restarted under normal conditions.

Water Chemistry

The makeup water supplied to each test section contained additives as shown in Table 2. Reagent grade chemicals were added to demineralized water in a 13 gallon polyethylene makeup tank and pumped 


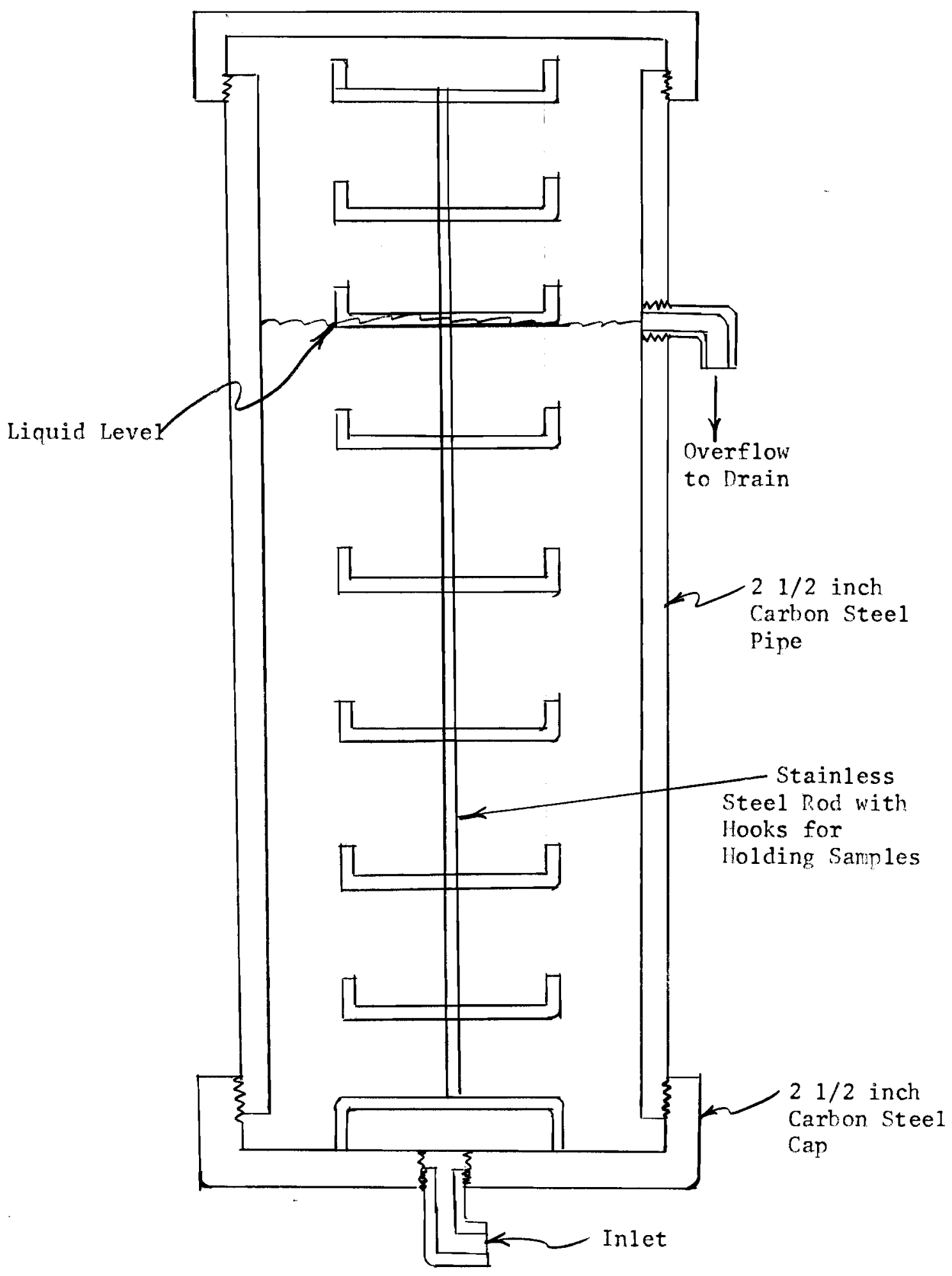

FIGURE 3

TEST SECTION APPARATUS SCHEMATIC 
through stainless steel lines to the test sections. The solution used in Test Chamber No. 6 simulated existing $N$ Reactor secondary system coolant (hydrazine, morpholine). Phosphate was tested at 50,100 and $1,000 \mathrm{ppm}$ phosphate ion concentration to determine the most effective concentration for stress corrosion cracking inhibition. Either hydrazine or sulfite was used in the phosphate solutions for oxygen scavenging. Hydrazine was used because this is currently employed in the steam generators and sulfite was employed because it is less expensive than hydrazine and with the high phosphate levels present it is no longer necessary to keep total solids at low levels. Test Section 7 water conditions were run with sulfite to separate out effects between sulfite and hydrazine additions. Morpholine was added to all solutions because it was not an additive under test and it was desired to keep this condition constant.

TABLE 2

NOMINAL WATER CHEMISTRY

Test

Section Phosphate Ion Sodium Sulfite Hydrazine Morpholine pH No. ppm ppm ppm ppm

$\begin{array}{lccccc}1 & 50^{*} & 100 & - & 2 & 10.3-10.8 \\ 2 & 100^{\star *} & 100 & - & 2 & 10.3-10.8 \\ 3 & 1000^{\star *} & 100 & - & 2 & 10.3-10.8 \\ 4 & 100 & - & 15 & 2 & 10.3-10.8 \\ 5 & 1000 & - & 15 & 2 & 10.3-10.8 \\ 6 & - & - & 15 & 2 & \\ 7 & - & 100 & - & 2 & \\ 8^{* \star \star \star} & 100 & 100 & - & 2 & 10.3-10.8\end{array}$

* $\quad 0.2 \mathrm{~g} / 1 \mathrm{Na}_{3} \mathrm{PO}_{4} \cdot 12 \mathrm{H}_{2} \mathrm{O}$

** $\quad 0.2 \mathrm{~g} / 1 \mathrm{Na}_{3} \mathrm{PO}_{4} \cdot 12 \mathrm{H}_{2} \mathrm{O}, 0.142 \mathrm{~g} / 1 \mathrm{Na} 2 \mathrm{HPO}_{4} \cdot 7 \mathrm{H}_{2} \mathrm{O}$

*** $2 \mathrm{~g} / 1 \mathrm{Na}_{3} \mathrm{PO}_{4} \cdot 12 \mathrm{H}_{2} \mathrm{O}, 0.725 \mathrm{~g} / 1 \mathrm{Na} \mathrm{H} \mathrm{HO}_{4} \cdot \mathrm{H}_{2} \mathrm{O}$

**** Control test section, used No. 2 makeup tank. 
Two known deviations from the desired conditions occurred during the test. At $11 / 2$ months the makeup solution for Test Chamber 2 was mistakenly added to Test Chamber 6; addition of this solution continued for 3 days before corrected. At the start of testing after the 4-month discharge the sulfite concentration in Test Chamber 3 was a factor of 10 higher than normal for a 3 -day period.

Liquid samples were saved at each discharge except the first and were analyzed at the completion of the test for $\mathrm{pH}$, chloride, conductivity, phosphate and sulfite. The results are shown in Table 3 . When insufficient sample was available for all analyses, the chloride analyses were run first since this analyses was deemed most applicable to any cracking phenomena which might be observed. Conductivities were not measured after the first set of samples since values obtained were so high (due to the large amount of chemicals added).

The chemical analyses showed that the actual operating conditions deviated from the desired conditions on several occasions. The $\mathrm{pH}$ was much lower for the solutions sampled at the third discharge than the desired limits and chlorides were found in numerous samples. The source of the chlorides is unknown. Chlorides were highly undesirable because they are known to promote stress corrosion cracking.

Oxygen analyses were made on two occasions to determine the effectiveness of the sodium sulfite and hydrazine additions in removing the oxygen. Samples from the test autoclaves were drained while at operating temperatures and pressures through an ion exchange column to remove all traces of sulfite and hydrazine which would interfere with the subsequent oxygen analyses (conducted by the Winkler method). Strict precautions were observed to keep oxygen out during the sampling procedure. The analyses (Table 3 ) showed that considerable oxygen remained in the test solutions; levels were reduced from a concentration of 9-10 ppm in the makeup solutions to a level of $0.2-3 \mathrm{ppm}$ in the test solutions. The high oxygen in combination with the chlorides produced an environment highly conducive to stress corrosion cracking of austenitic stainless steel. 
TABLE 3

WATER ANALYSES

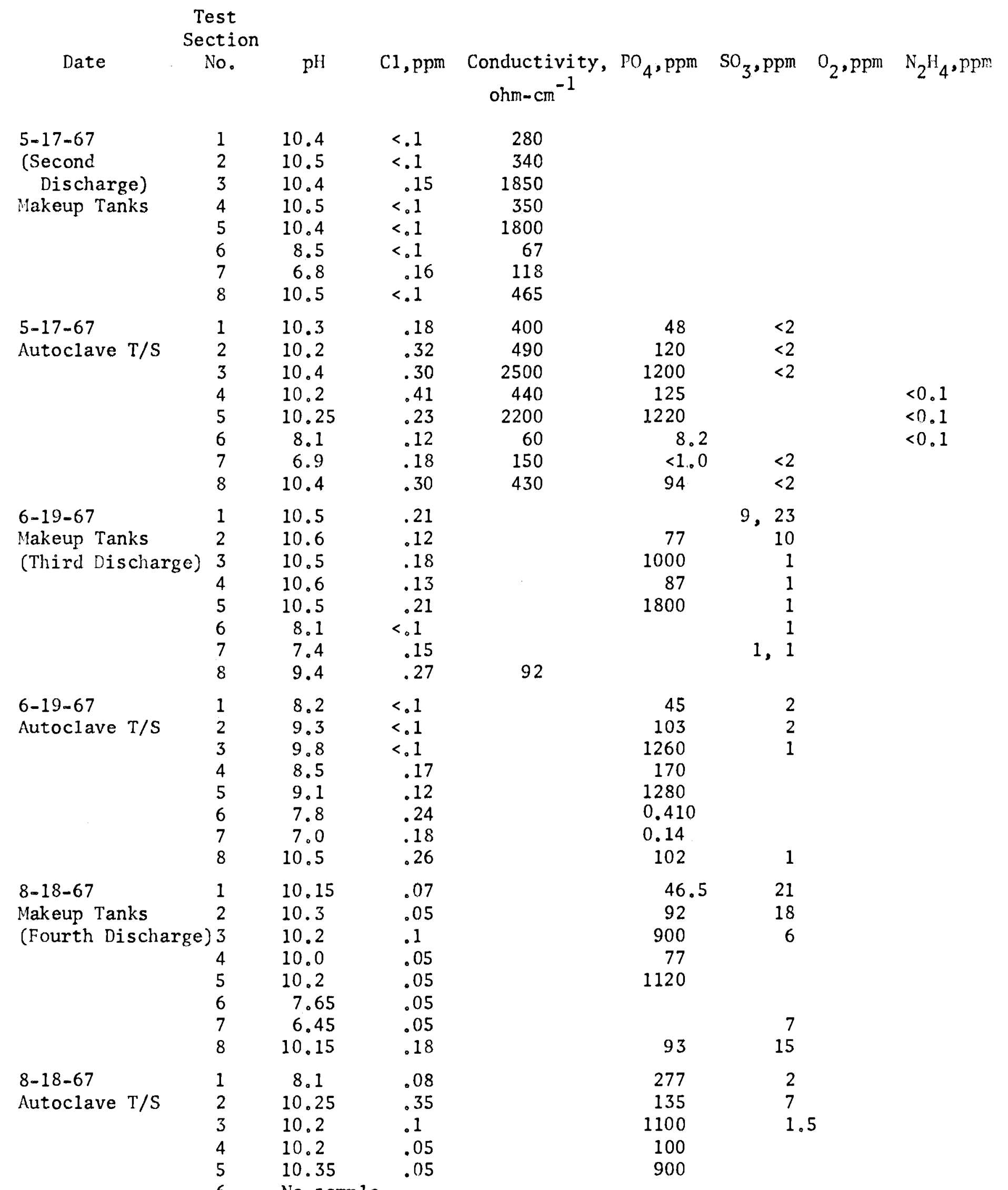


TABLE 3 (Continued)

\begin{tabular}{|c|c|c|c|c|c|c|c|}
\hline $\mathrm{Se}$ & $\begin{array}{l}\text { est } \\
\text { ction } \\
\text { No. }\end{array}$ & $\mathrm{pH}$ & $\mathrm{Cl}, \mathrm{ppm}$ & 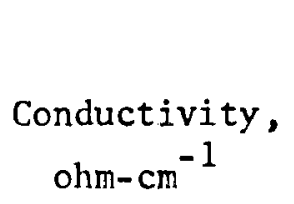 & $\mathrm{PO}_{4}, \mathrm{ppm}$ & $\mathrm{SO}_{3}, \mathrm{ppm}$ & $\mathrm{o}_{2}, \mathrm{ppm}$ \\
\hline $\begin{array}{l}(8-18-67) \\
\text { (Autoclave T/S) }\end{array}$ & $\begin{array}{l}7 \\
8\end{array}$ & $\begin{array}{l}6.55 \\
9.8\end{array}$ & $\begin{array}{r}<.05 \\
.48\end{array}$ & & 93 & $\begin{array}{l}1 \\
1\end{array}$ & \\
\hline $\begin{array}{l}\text { 9-14-67 } \\
\text { Autoclave T/S } \\
\text { (Special } \\
\text { Analysis) }\end{array}$ & $\begin{array}{l}1 \\
2 \\
3 \\
4 \\
5 \\
6 \\
7\end{array}$ & & & & & $\begin{array}{r}12 \\
9 \\
3 \\
\\
\\
0.2\end{array}$ & $\begin{array}{l}0.16 \\
0.52 \\
0.20 \\
\text { Trace } \\
1.0 \\
0.16 \\
0.20\end{array}$ \\
\hline $\begin{array}{l}10-18-67 \\
\text { Makeup Tanks } \\
\text { (Fifth Discharge) }\end{array}$ & $\begin{array}{l}1 \\
2 \\
3 \\
4 \\
5 \\
6 \\
7 \\
8\end{array}$ & $\begin{array}{l}10.35 \\
10.4 \\
10.3 \\
10.3 \\
10.35 \\
8.05 \\
6.95 \\
10.25\end{array}$ & $\begin{array}{l}<.05 \\
<.05 \\
<.05 \\
<.05 \\
<.05 \\
<.05 \\
<.05 \\
<.05\end{array}$ & & $\begin{array}{r}45 \\
89 \\
890 \\
93 \\
1000 \\
\\
100\end{array}$ & $\begin{array}{l}23 \\
27 \\
10\end{array}$ & \\
\hline $\begin{array}{l}10-18-67 \\
\text { Autoclave T/S }\end{array}$ & $\begin{array}{l}1 \\
2 \\
3 \\
4 \\
5 \\
6 \\
7 \\
8\end{array}$ & $\begin{array}{l}10.4 \\
10.35 \\
10.35 \\
\\
5.95 \\
6.3 \\
10.1\end{array}$ & $\begin{array}{r}1.66 \\
.06 \\
<.05 \\
<.05 \\
.026 \\
.032 \\
<.05 \\
<.05\end{array}$ & & $\begin{array}{r}179 \\
1140 \\
119 \\
\\
\\
99\end{array}$ & $\begin{array}{l}4 \\
1\end{array}$ & \\
\hline $\begin{array}{l}\text { 12-11-67 } \\
\text { Autoclave T/S } \\
\text { (Special } \\
\text { Analysis) }\end{array}$ & $\begin{array}{l}1 \\
2 \\
3 \\
4 \\
5 \\
6 \\
7\end{array}$ & & & & & $\begin{array}{r}4 \\
24 \\
234\end{array}$ & $\begin{array}{l}\text { Undetectable } \\
.36 \\
1.2 \\
.44 \\
2.88 \\
1.12 \\
1.68\end{array}$ \\
\hline $\begin{array}{l}12-19-67 \\
\text { Makeup Tanks } \\
\text { (Sixth Discharge) }\end{array}$ & $\begin{array}{l}1 \\
2 \\
3 \\
4 \\
5 \\
6 \\
7 \\
8\end{array}$ & $\begin{array}{c}10.4 \\
10.3 \\
10.35 \\
10.35 \\
9.45 \\
7.6 \\
6.05 \\
9.75\end{array}$ & $\begin{array}{l}<.05 \\
<.05 \\
<.05 \\
.013 \\
<.05 \\
<.05 \\
<.05 \\
<.05\end{array}$ & & $\begin{array}{c}49.5 \\
97 \\
980 \\
74 \\
980\end{array}$ & $\begin{array}{r}1 \\
23 \\
84\end{array}$ & \\
\hline $\begin{array}{l}12-19-67 \\
\text { Autoclave T/S }\end{array}$ & $\begin{array}{l}1 \\
2 \\
3 \\
4 \\
5 \\
6 \\
7\end{array}$ & $\begin{array}{r}10.75 \\
9.45 \\
9.15\end{array}$ & $\begin{array}{r}.1 \\
1.84 \\
<.05 \\
<.05 \\
.26 \\
.32 \\
<.05\end{array}$ & & $\begin{array}{r}225 \\
1370 \\
143\end{array}$ & 12 & \\
\hline
\end{tabular}


Sample Examination Procedures

Upon discharge, the stressing screws were all removed and the samples examined at $40 \mathrm{X}$ for stress corrosion cracking. Practically all the cracks observed were found at this examination. The samples were then weighed, the corrosion films stripped, and then reweighed to provide weight change data from which the corrosion penetrations were calculated. The film stripping procedure consisted of immersing the samples one hour in a $105{ }^{\circ} \mathrm{C}$ solution of $18 \% \mathrm{NaOH}-3 \% \mathrm{KMnO} 44^{-79 \%} \mathrm{H}_{2} \mathrm{O}$ to condition the oxides for subsequent removal in a fjve-minute dip in room-temperature solution of $50 \% \mathrm{HC} 1-50 \% \mathrm{H}_{2} \mathrm{O}$ inhibited with propynol. The acid solution was thoroughly rinsed from the samples to prevent any residual chlorides remaining. The samples were immediately re-examined at $40 \mathrm{X}$ to determine if any additional stress-corrosion cracking not found during the first examination was present.

\section{RESULTS}

Stress-Corrosion Cracking

Of all the alloys tested, only the 304 stainless steel tubing from the $\mathrm{N}$ Reactor steam generators exhibited stress corrosion cracking. Even the 304 stainless steel sheet material heat treated to simulate the heat treatment received by the steam generator tubing did not exhibit any stress corrosion cracking.

Stress corrosion cracking of the steam generator tubing was completely stopped in some of the solutions while it progressively got worse with time in other solutions as shown in Table 4. At the first discharge ( 2 weeks) samples cracked only at the vapor and interface locations in the autoclave containing sulfite-morpholine treated water. At one month, cracking was also observed in the liquid phase of this environment and at the interface and immersed positions in the autoclave containing hydrazine-morpholine treated water. The hydrazinemorpholine treated water simulated present water chemistry in the $\mathrm{N}$ Reactor steam generators.

With increasing exposure time, cracking was extended to samples in the vapor and interface positions in all water treatments. This 
TANLF A

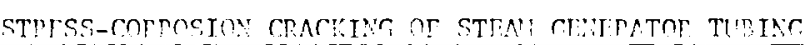

location

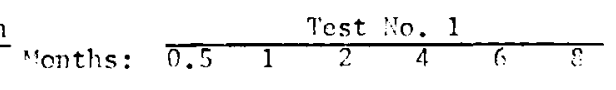

Vanor

(Tensile stross on no)

Interface

(Tensile stress on $\mathrm{nm}$ )

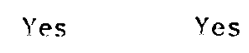

Test io. 2
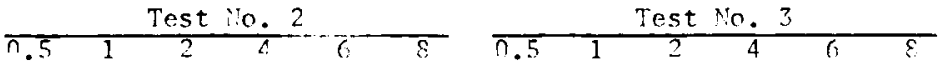

Yes Yes

Yes

yes

Liquici

(Tensile Stress on ni?)

Liquid

(Tensile Stress on In)

Nominal Solution Composition

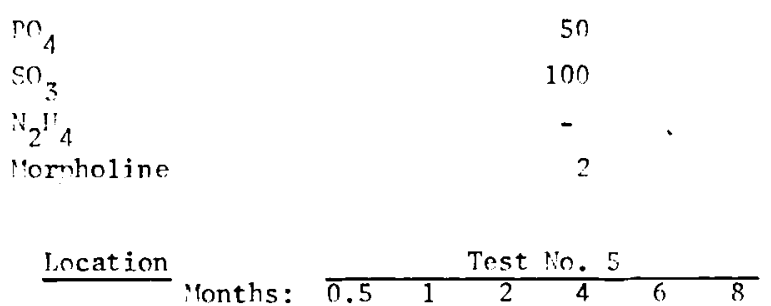

Vanor

(Tensile Stress on $n$ )

Interface

(Tensile Stress on $n$ )

Liquiar!

(Tensile Stress on $n$ )

Lianid

(Tensile stress on $\mathrm{J} T$ )

Yes Yes Yes

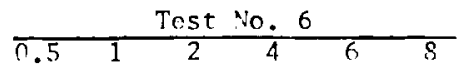

100

100

$-$

2

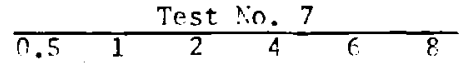

Yes Yes

Yes

Yes Yes

Yes Yes Yes Yes Yes

Yes Yes
Yes

Yes
Yes

1000

100

$-$

2

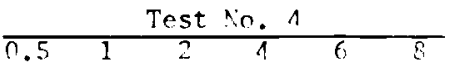

Yes Yes les yes

Yes ves Yes Yes

Unrinal Solution Comnosition

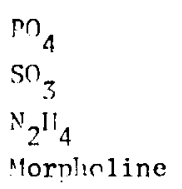

1000
-
15
2

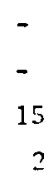

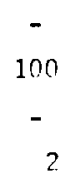

100
100
-
2


is logical since the samples at these locations would not benefit from any of the inhibiting effects of the chemical additives to the treated waters. Phosphate solutions continued to prevent cracking on immersed samples for six months at which time one small crack was found on a sample immersed in the autoclave containing $1000 \mathrm{ppm}$ phosphate, $15 \mathrm{ppm}$ hydrazine and $2 \mathrm{ppm}$ morpholine. At the final discharge ( 8 months) a small crack was found on another sample removed from this location and a small crack was found on a sample immersed in $1000 \mathrm{ppm}$ phosphate, $100 \mathrm{ppm}$ sulfite and $2 \mathrm{ppm}$ morpholine. There were no cracks found during any time of the test on samples immersed in $50 \mathrm{ppm}$ phosphate, $100 \mathrm{ppm}$ sulfite, $2 \mathrm{ppm}$ morpholine solution or in $100 \mathrm{ppm}$ phosphate, $100 \mathrm{ppm}$ sulfite, $2 \mathrm{ppm}$ morpholine solution. In contrast, some of the samples immersed in solutions containing no phosphate had completely failed within a few months of testing.

Except for samples in Solution 7, all failures which occurred on immersed samples were intergranular failures on ID surfaces. Typical examples are shown in Figure 4.

\section{Visual Appearances}

The samples were all a gold color at the first discharge and the Inconel and stainless steel samples remained this color for the entire test. The one exception was that the stainless steel in Solution No. 1 (50 ppm phosphate, 100 ppm sulfite) was black at the end of the test. The carbon steel samples formed a black oxide after one month and remained this color for the entire test. Other than the stress cracking noted above the only other localized corrosion was one 4 mil diameter pit on the Incoloy 800 sample exposed two months in Solution 7 (sulfitemorpholine) and numerous pits on the carbon steel samples. During the first four months of testing no pitting occurred on carbon steel in Solutions 4, 5, and 7 (see Table 2 for solution compositions) while tiny pits less than $1 \mathrm{mil}$ diameter and 1 mil. deep formed a honeycomb structure on the edges of the samples in Solutions $2,3,6$, and 8 . Pits up to 2 mils wide and deep were found on the edges and at the bolt hole of the carbon steel sample exposed in Solution 1 for four months. 
Pitting on carbon steel exposed in all solutions was found after 8 months exposure. The pits were less than $1 \mathrm{mil}$ diameter and $1 \mathrm{mil}$ deep on samples in Solutions 3,5,6, and 7; 1 to 2 mils deep on samples in Solutions 1 and $4 ; 2$ to $3 \mathrm{mils}$ deep on the sample in Solution 2; and 5 to $10 \mathrm{mils}$ deep on the sample in Solution 8. Most of the deeper pits were found either in the crevice area at the bolt hole or on the sample's outer edge.

Uniform Corrosion Losses

Uniform corrosion losses calculated from descaled weight loss data were negligible for all samples except the carbon steel. These data are shown in Table 5. Total corrosion losses for carbon steel after eight months exposure in Solutions 1 through 8 , respectively were $0.064,0.072,0.081,0.027,0.038,0.049,0.184$ and $0.29 \mathrm{mils}$. While not negligible these penetrations are sufficiently low that equipment failure due to uniform corrosion of steel would not be a significant concern in the use of any of the water chemistries employed in these tests.

\section{DISCUSSION}

The environments to which the steam generator tubing were exposed during these tests were extremely conducive to stress corrosion cracking yet very few cracks occurred on samples immersed in phosphate solutions. In fact, stress-corrosion cracking did not occur in three of the five autoclaves containing phosphate solutions while severe cracking occurred in all three solutions without phosphate additions. The corrosive environment was caused by the combined presence of chlorides and oxygen, a combination which is well known to cause stress corrosion cracking. of austenitic stainless steels. The fact that the phosphate solutions significantly reduced stress corrosion cracking under these conditions is very encouraging and it is possible that under reactor operating conditions where better control on chlorides and oxygen can be maintained, stress corrosion cracking could be entirely eliminated. 
FIGURE 4

TYPICAL STRESS-CORROSION CRACKING OF STEANI GENERATOR TUBING

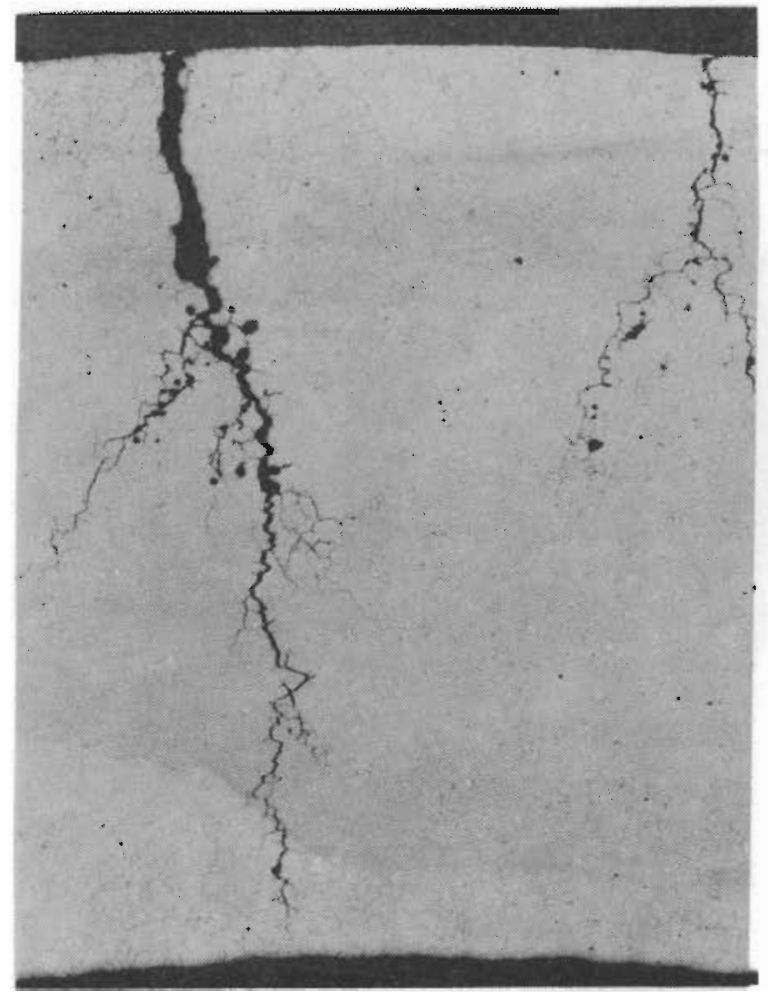

Immersed two months in $100 \mathrm{ppm}$ sulfite, $2 \mathrm{ppm}$ morpholine. OD surface, $75 X$
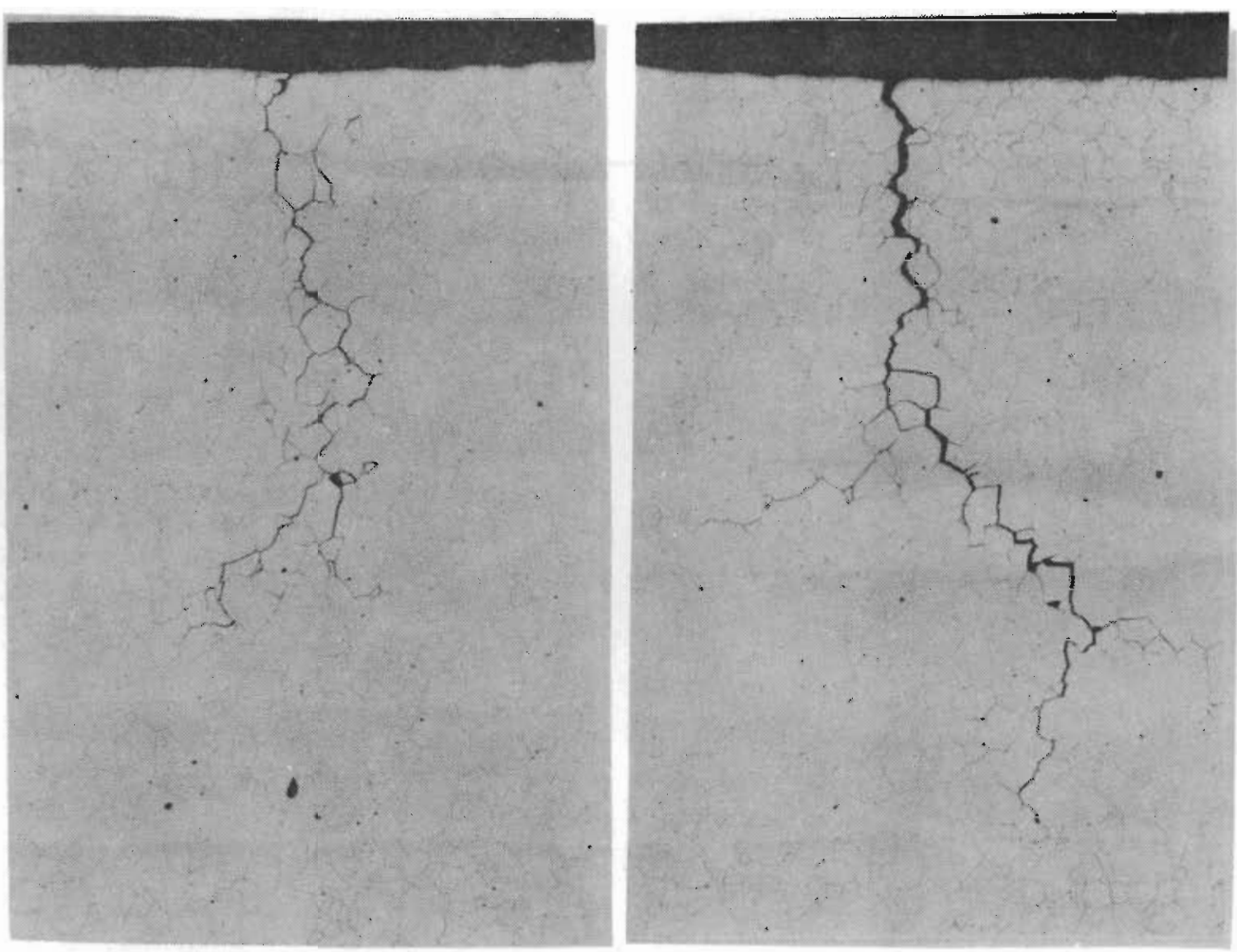

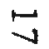

Immersed six months in $15 \mathrm{ppm}$ hydrazine, $2 \mathrm{ppm}$ morploline. ID surface, $75 \mathrm{X}$
Innersed eight months in $1000 \mathrm{ppm}$ phosphate, $100 \mathrm{ppm}$ sulfite. ID surface, $75 X$ 
TANIT: 5

inIfor": compnsion, "ils

\begin{tabular}{|c|c|c|c|c|c|c|c|c|c|c|c|c|c|}
\hline \multirow{3}{*}{$\therefore 110 y$} & \multirow{2}{*}{$\frac{\text { Location }}{\text { Tnnths: }}$} & \multicolumn{6}{|c|}{ Test No. 1} & \multicolumn{6}{|c|}{ Test No. 2} \\
\hline & & 7.5 & 1 & 2 & 4 & 6 & 8 & 0.5 & 1 & 2 & 4 & 6 & $\overline{8}$ \\
\hline & Vanor &.$n n \theta$ & $.00 ? n$ & .002 & .004 & .0047 & .0012 & .0043 & $.007 ?$ & .0072 & .006 & .0034 & $.0 \cap 68$ \\
\hline & linnuic' & . nna & .0047 & .003 & .0035 & $.0 \cap 43$ & $.0 \cap 4$ & .0069 & $.06 ?$ & .006 & .0069 & .0081 & .0124 \\
\hline \multirow[t]{2}{*}{ Incoloy } & Vonor & $n$ & .0004 & . & . & $.0 n \cap 4$ & .0023 & . กחก4 & $.0 n 18$ & .0046 & .0046 & .0009 & . nnno \\
\hline & i, ietuici & .002 & .0026 & $.002=$ & .0022 & .0025 & .203 & .003 & .0033 & $.0 \cap 2.3$ & .0028 & .0032 & .0023 \\
\hline \multirow[t]{3}{*}{ itl in } & ropror &.$\cap n 5$ & &.$n 076$ & .0172 & .009 & .009 & .005 & .0081 & nח81 & .0058 & $.005 \varepsilon$ &. $\cos 1$ \\
\hline & Intorfuco & .005 & .0072 & .0076 & - & .0076 & .8074 & . ición & .0001 & .012 & .0094 & .022 & .0070 \\
\hline & $\begin{array}{r}\text { Jinuic: } \\
\text { In }\end{array}$ & . .007 & $\begin{array}{l}.0059 \\
.0 n 05\end{array}$ & . & $\begin{array}{l}.0385 \\
.0 n 21\end{array}$ & $\begin{array}{l}.011 \\
.0084\end{array}$ & $\begin{array}{l}.00 n 5 \\
.014\end{array}$ & $\begin{array}{l}.006 \\
.0 n 9.1\end{array}$ & $\begin{array}{l}.0094 \\
.00 n e\end{array}$ & $\begin{array}{l}.010 \\
.0 n n 4\end{array}$ & $\begin{array}{l}.010 \\
.0099\end{array}$ & $\begin{array}{l}.009 \\
.009\end{array}$ & $\begin{array}{l}.0055 \\
.0095\end{array}$ \\
\hline $\begin{array}{l}3 \text { the, } \\
\text { unsensitized }\end{array}$ & Liquia & .0025 & .0029 & .003 & .0046 & .005 & .0058 & .002 & .0025 & .0029 & .0038 & .005 & .0046 \\
\hline $\begin{array}{l}.304 \$ S, \\
\text { sensitized }\end{array}$ & Liquid & .0028 & .0062 & .0046 & .0042 & .008 & .010 & + & .0067 & .005 & .075 & .0067 & .0084 \\
\hline$\therefore 212 C$ & Liquia & .0015 & .030 & .039 & .047 & .057 & .064 & .014 & .0278 & .038 & .051 & .066 & .072 \\
\hline \multirow[t]{2}{*}{$\$ 110 y$} & \multirow{2}{*}{$\frac{\text { Location }}{\text { tontis: }}$} & \multicolumn{6}{|c|}{ Test No. 4} & \multicolumn{6}{|c|}{ Test No. 5} \\
\hline & & 0.5 & 1 & 2 & 4 & 6 & $S$ & 0.5 & 1 & 2 & 4 & $\overline{6}$ & 8 \\
\hline \multirow[t]{2}{*}{ Inconel 600} & Vapor & .002 & .002 & .003 & .0026 & .0038 & .0021 & .002 & .0026 & .0047 & .004 & .004 & .003 \\
\hline & liquic: & .002 & .0043 & .0043 &.$n 08$ & .0025 & .0068 & .003 & .0026 & .009 & .0043 & .0041 & .006 \\
\hline \multirow[t]{2}{*}{ Incoloy 800} & Vapor & .002 & .0033 & .0009 & .0000 & .0013 & .009 & .0009 & .0027 & .009 & .0000 & .0013 & .069 \\
\hline & Liquid & .002 & .0023 & .002 & .0046 & .0023 & .0000 & .0013 & .0041 & .003 & .009 & .0055 & .0013 \\
\hline \multirow[t]{3}{*}{ Tubing } & Vanor & .005 & .004 & .008 & .0045 & .0054 & .0081 & .0099 & .0046 & .003 & .011 & .0067 & .0054 \\
\hline & Interface & .003 & .006 & .008 & .029 & .0054 & .0049 & .0037 & .0054 & .004 & .0036 & .0049 & .004 \\
\hline & $\begin{array}{r}\text { Liquid } n \\
\text { In }\end{array}$ & $\begin{array}{l}.004 \\
.004\end{array}$ & $\begin{array}{l}.0067 \\
.0067\end{array}$ & $\begin{array}{l}.0049 \\
.0049\end{array}$ & $\begin{array}{l}.003 \\
.0058\end{array}$ & $\begin{array}{l}.0067 \\
.0056\end{array}$ & $\begin{array}{l}.0050 \\
.0049\end{array}$ & $\begin{array}{l}.0046 \\
.0023\end{array}$ & $\begin{array}{l}.006 \\
.0092\end{array}$ & $\begin{array}{l}.005 \\
.004\end{array}$ & $\begin{array}{l}.005 \\
.0072\end{array}$ & $\begin{array}{l}.0072 \\
.0070\end{array}$ & $\begin{array}{l}.006 \\
.0035\end{array}$ \\
\hline $\begin{array}{l}\text { 3n4Ss, } \\
\text { ursensitized }\end{array}$ & Liquie & .0021 & .0017 & .002 & .0004 & .0029 & .0021 & .0025 & .0025 & .003 & .0021 & .0025 & .0042 \\
\hline $\begin{array}{l}304 S S, \\
\text { sersitizer! }\end{array}$ & Liquic: & .004 & .005 & .0046 & .004 & .0037 & .0016 & .0046 & .0046 & .005 & .0042 & .0063 & .0079 \\
\hline$\therefore 2120$ & Liquid & .0009 & .038 & .023 & .018 & .0197 & .027 & .0197 & .026 & .02 & .023 & .031 & .0376 \\
\hline Allov & Location & \multicolumn{6}{|c|}{ Test $\mathrm{No} .7$} & \multicolumn{6}{|c|}{ Test No. 8} \\
\hline & Tonths: & 0.5 & 1 & 2 & 4 & 6 & 8 & $\overline{0.5}$ & 1 & 2 & 4 & 6 & 8 \\
\hline \multirow[t]{2}{*}{ Inconel wo } & Vaoor &.$n \cap 26$ & .0039 & .008 & .0065 & .003 & .006 & .0056 & .0082 & .006 & .003 & .0047 & .005 \\
\hline & Jiọuid & .0034 & .0043 & .016 & .0069 & .023 & .0137 & .006 & .0064 & .0055 & .003 & .0038 & .003 \\
\hline \multirow[t]{2}{*}{ Incoloy sno } & Vapor & .0023 & .0046 & .006 & .0028 & .0018 & .0028 & .0018 & .0046 & .0036 & .0032 & .0023 & .00092 \\
\hline & Liqquít! & .0032 & .078 & .012 & .0037 & .013 & .0000 & .0023 & .0074 & .004 & .0014 & .0032 & .00184 \\
\hline \multirow[t]{3}{*}{ ?ulyinr } & lapor & .0051 & .0083 & .015 & .017 & .012 & .037 & .0058 & .0076 & .009 & .0054 & .009 & .0063 \\
\hline & Interface & $.0 \cap 27$ & .0074 & .011 & .0041 & .095 & .0184 & .0063 & .0067 & .009 & .005 & .0067 & .008 \\
\hline & $\begin{array}{r}\text { I.ig̣nid } 0 \mathrm{~T} \\
\text { ID }\end{array}$ & $\begin{array}{l}.0138 \\
.0009\end{array}$ & $\begin{array}{l}.013 \\
.0138\end{array}$ & $\begin{array}{l}.010 \\
.013\end{array}$ & $\begin{array}{l}.0035 \\
.010\end{array}$ & $\begin{array}{l}.0045 \\
.0067\end{array}$ & $\begin{array}{l}.0157 \\
.0149\end{array}$ & $\begin{array}{l}.0049 \\
.0036\end{array}$ & $\begin{array}{l}.0077 \\
.0059\end{array}$ & $\begin{array}{l}.007 \\
.0076\end{array}$ & $\begin{array}{l}.005 \\
.0041\end{array}$ & $\begin{array}{l}.009 \\
.0066\end{array}$ & $\begin{array}{l}.0041 \\
.0052\end{array}$ \\
\hline $\begin{array}{l}3045 S, \\
\text { unsensitized! }\end{array}$ & Liquisi & .0017 & .0105 & .012 & .0054 & .0130 & .0146 & .00042 & 2.0028 & .003 & .0084 & .0037 & .0042 \\
\hline $\begin{array}{l}3045 \$ \\
\text { sensitizer! }\end{array}$ & liquid & .00046 & 0.0085 & .010 & .0000 & .012 & .0117 & .0013 & .0038 & .007 & .002 & .0042 & .0059 \\
\hline$\therefore=120$ & Linuic: & .036 & .173 & .074 & .287 & .109 & .184 & .0103 & $.018 \mathrm{~S}$ & .041 & .098 & .333 & .29 \\
\hline
\end{tabular}

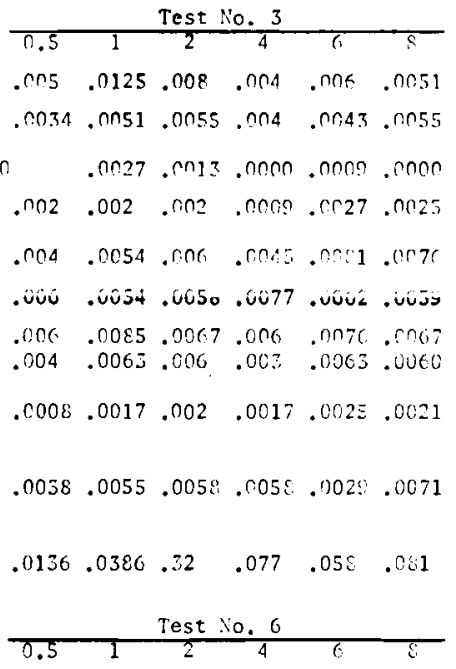

$.0039 .0064 .0047 .003 \quad .0035 .0025$ $\begin{array}{lllll}.0035 .0064 .006 \quad .0038 & .0043 .0043\end{array}$ .0004 .0023 .009 .0000 .009 .0046 $\begin{array}{lllll}.0023 .0037 .003 & .0028 .003 & .0004\end{array}$ $\begin{array}{lllll}.0032 & .0054 .004 & .0045 & .0036 & .003 \%\end{array}$ .0051 .0074 .0058 .0041 .0062 .0051 $\begin{array}{llllll}.0046 .011 & .008 & .0045 & .0063 & .0063\end{array}$ .0064 .0074 .005 .005 .0048.0030

.0017 .0038 .0038 .0025 .0038 .0017

.0042 .0034 .005 .0038 .0042 .0034 $.0235 .038 \quad .053 .046 .066 .04 ?$ 
Phosphate addition is presently only feasible on the secondary or shell side of the steam generators since the coolant on the primary or tube side passes through the reactor and the effects of phosphate under these conditions are unknown. Use of phosphates on the secondary side will be at conditions where a large amount of favorable experience is available, i.e., secondary system chemistry conditions would closely match conditions employed in normal boiler water chemistries. Fortunately, almost all the tubing failures originate on the secondary side of the tubing。

\section{ACKNOWLEDGEMENTS}

The assistance of $R$. D. Henry in sample preparation and inspection and the assistance of $R_{0} A_{0}$. Thiede and $S$. D. Deusser in operating the autoclaves is gratefully acknowledged. 
BNWL-753

REFERENCES

1. W. D. Bainard, W. K. Kratzer, A. P. Larrick. Chemical Decontamination of Large Nuclear Steam Generators, A Case History, DUN-SA-62, February 28, 1968. Unclassified.

2. W. E. Berry, et.a1. The Shippingport Atomic Power Station (PWR), BMI-1764, 2-24-66.

3. S. P. Rideout and R. F. Mittleberg. Factors Controlling Chloride Stress Corrosion of Type 304 Stainless Steel, CoNF-778-3, October 1964. 
ONSITE DISTRIBUTION

Copy Number

1

2

3

4

5

6-10

11

12

13

$14-18$

19-20

\section{Battelle-Northwest}

J. A. Ayres

D. R. de Halas

R. L. Dillon

B. Griggs

H. Harty

A. P. Larrick (5)

L. D. Perrigo

R。H. Purcell

R. E. Westerman

Technical Information Files (5)

Technical Publications (2)

\section{Douglas United Nuclear}

21
22
23
24
25
26
27
28
29
30
31
32
33
34
35
36
37
$38-40$

T. W. Ambrose

W. D. Bainard

J. L. Benson

G. K. Dykeman

J. H. Fastabend

M. L. Faught

T. M. Hall

D. L. Hovorka

H. F。 Jensen

W. K. Kratzer

D. S. Lewis

$M$, Lewis

C. E. Love

J.S. McMahon

N. R. Miller

D. W. Peacock

J. W. Riches

Technical Information Files (3)

OFFSITE DISTRIBUTION

Copy Number

41

AEC, RL

C. L. Robinson

Technical Library

$42-43$

AEC, RDT Site Representative

.P.G. Holsted (2)

44-45

AEC, Chicago Patent Group

G. Ho Lee

R. K. Sharp 
OFFSITE DISTRIBUTION (Continued)

Copy Number

$46-50$

$51-53$
AEC, DTIE

For UC-80 Distribution (5)

Battelle Memorial Institute (3) 